TP Periodica Polytechnica

Social and Management Sciences

24(2), pp. 136-148, 2016

DOI: $10.3311 /$ PPso. 7803

Creative Commons Attribution (i)

RESEARCH ARTICLE

\section{Regional Level of Sustainability - Two Hungarian Case Studies}

\author{
János Szlávik ${ }^{1}$, Hajnalka Csáfor ${ }^{1}$, Tekla Sebestyén Szép ${ }^{2 *}$
}

Received 11 November 2014; accepted after revision 25 January 2016

\begin{abstract}
The basic aim of sustainable spatial development is to develop and achieve a program which is based on the principle of sustainable development with the active collaboration of local governments and the support of the population. In our paper we present the main criteria of sustainable spatial development and we examine the main requirements created by the European Union for spatial planning. In our publication we discuss the presence of aspects of sustainability in the spatial development frameworks of the Heves and Borsod-Abaúj-Zemplén Counties. We highlight the main similarities and differences between these two approaches.
\end{abstract}

\section{Keywords}

spatial development, sustainability, social awareness, Heves County, Borsod-Abaúj-Zemplén County, Hungary

\footnotetext{
${ }^{1}$ Faculty of Economics and Social Sciences, Eszterházy Károly College,

Eszterházy tér 1., H-3300 Eger, Hungary

${ }^{2}$ Institute of World and Regional Economics, University of Miskolc,

Miskolc-Egyetemváros, H-3515 Hungary

${ }^{*}$ Corresponding author, e-mail: regtekla@uni-miskolc.hu
}

\section{Introduction}

In this paper we discuss the presence of aspects of sustainability in spatial development frameworks in Hungary in 2013 - for the period 2014 - 2020 - focusing on Heves and Borsod-Abaúj-Zemplén Counties ${ }^{1,2}$. The presence of the criteria for sustainable spatial development is examined mainly in the target system of the plan and in how strongly the targets are related to the key issues of the transition to sustainability. We focus on the following research questions:

1. What kinds of European strategies have corresponding spatial development frameworks?

2. What are the main environmental aspects of these strategies?

3. What is the basic aim of this sustainable spatial development?

4. How do the three strategic dimensions of sustainable development relate to the human dimension?

5. What are the main criteria of sustainable spatial development?

6. How do these criteria of sustainability appear in the examined frameworks?

7. What are the main differences between the concepts used Borsod-Abaúj-Zemplén and in Heves Counties?

\section{Sustainability in the regional development 2.1 The presence of sustainability in the policy documents of the European Union aiming local programs}

Analyzing the development policy framework of the Union (Natural Resources Defense Council, 2012) it can be concluded that the sustainable development; including the receiving -the sustainable and efficient use of the resources, and the careful sustainable maintenance of the natural social and cultural values, is an essential point during the integrated improvement of regions.

\footnotetext{
1 The authors took part in the process of spatial planning in both counties.

2 Hereinafter using the abbreviation of HMFTK to the spatial development framework of Heves county and abbreviation of BAZMFTK to the spatial development framework of Borsod-Abaúj-Zemplén county.
} 
The Lisbon strategy, aimed in 2000 at making the EU competitive as a knowledge economy, was followed by the Europe 2020 growth strategy, valid for 10 years, that also provides the implementing of smart, sustainable and inclusive growth. The strategy gives the maximum priority to employment, education, research and innovation, the facilitation of social inclusion, poverty alleviation, fight against climate change and energy shortages.

The Territorial Agenda of the European Union 2020 (Informal Ministerial Meeting of Ministers responsible for Spatial Planning and Territorial Development, 2011) showing a strategic guideline for the regional development, also includes a priority for the integrated development of towns and rural regions with specific natures, as well as encouraging global competitiveness of local economies, handling and connecting ecological, regional and cultural values.

The cohesion policy is the primary framework concerned with the primary aim of the reduction of the social-, economic- and regional inequalities within the Union, as well as the increase of the EU's competitiveness (Bujdosó et al., 2013). Connected to the strategy of Europe 2020, the cohesion policy, as a common means of programming, is determined by the strategy's Common Strategic Framework for the planning period 2014-2020. Within this framework eleven thematic objectives are defined, providing strategic guidelines for regional development to the member states in the planning period. These thematic objectives are completely consistent with the interest of our country and its possible future trends. Additionally the majority meets the criteria of a regional sustainable development (with more details in Kawakami et al., 2013 and Delladetsima, 2012):

- developing the research, the technical development and the innovation

- developing access, use and quality of the information and communication technology

- developing the competitiveness of small and mediumsized enterprises (SMEs) and fishing industries

- supporting the low carbon dioxide emission economy in all industries

- supporting the adaptation to climate change, the risk prevention and handling

- promoting environmental protection and resource efficiency

- promoting sustainable transport and eliminating capacity problems in the main network infrastructure

- promoting employment and supporting labor mobility

- promoting social inclusion and the fight against poverty

- investments in the fields of education, skills development, and the life-long learning

- developing institutional capacity and effective government.

The Common Agricultural Policy (CAP, 2013) basically defines Hungary's strategy in connection with agriculture and rural areas. The main aims of the multifunctional European agricultural model are supporting sustainable farming with natural sources and "green growth", ensuring the competitiveness of the sector and the development of local farms and markets. (Ruszkai and Kovács, 2013).

According to the Union, a territorial approach and the harmony of sectoral policies are essential in the planning period. Harmonizing the social-cultural, economic and natural-ecological views is a key factor to foster the sustainability that is mainly possible in specific geographical units. Significant different effects can be realized in each activity among regions having different characteristics. Therefore one of the most important elements of mainstreaming sustainability is the implementation of spatial thinking and territorial cohesion and views during the planning, development, evaluation and monitoring processes.

The three dimensions of sustainable development (natural, social, economic):

- Nature: living in harmony with nature includes a responsibility to act in preserving the natural values (with a priority at the level of biodiversity). In Europe, including Hungary, nature, in today's form, is a living system shaped by human actions, which can survive at present levels only by the result of conscious human actions, e.g. A forest field or a country grassland can be weedy in the case of not being grazed or mowed. Invasive species, such as ragweed or acacia, diffuse when the land is not farmed. Conservation and farming are not mutually exclusive definitions. If farming in valuable natural regions is done with an environmentally friendly attitude (ecological farming, ecotourism, etc.) then natural values will survive and even develop. Gardens on habitations are also the part of nature and their cultivation is an important task.

- Social awareness and sustainability: From the point of view of sustainable development, man shall be understood to be not only a worker but also as a complex individual. A region, county or habitation can live in a suitable way only if people living there have jobs, so that their labor capacity is useful. Therefore a key objective in regional development concept is improving the employment-intensive economy.

- Economics: A successful county sustainable spatial development program can be realized only with the support of business sector responsible also for local society. This process is helped by an institutional system encouraging cooperation and properly functioning local and specific development of taxes and other economic regulators. It is problematic to describe how this affects the local social activity of companies.

However the human element forms the center of these three dimensions, concerned with who meets the needs of the present 
Table 1 Criteria of sustainable spatial development

\begin{tabular}{ll}
\hline Objectives and priorities & \\
\hline Local and regional sustainability & Value storing economy with renewable resources \\
Global sustainability & Sectoral integration \\
Attractive rural world & Integrated product policy \\
Livable towns & Decentralized developments \\
Value storing, diversified economy & "Produce locally, consume locally" \\
Diligence and altruism & "Work locally" \\
Ethical operation & Quality products, innovation \\
Conscious food-production and consumption & Production cooperation within the region \\
Nature conservative spatial development & Sparing with exhaustible values \\
Ecological developments & Social equity \\
Pollution prevention and minimization & Knowledge based spatial development \\
Minimizing of multiplier effects & Social cohesion \\
Dematerialization & Solidarity, regional cohesion \\
Recycling and resource efficiency & Social participation \\
Justice and social equality between generations & Local eco-social interest and social responsibility \\
\hline Source: own compilation on Pálvölgyi and Csete, 2011:pp.471-472. \\
\end{tabular}

and those of future generations. (Szlávik, 2013) The basic aim of sustainable spatial development is to improve and achieve a program which is based on the principle of sustainable development with the active collaboration of local governments and the support of the population (Kiss, 2014). With the assistance of sustainability in spatial planning, a region can be organized such that it is considered as a home by its population, in which they and their children living in these towns and villages now and in the future, feel at home (Kovács, 2012). The human factor appears in our analysis as 4th key element.

\subsection{Methodology - Criteria of examination of sustainable spatial development}

An important practical issue is how the criteria of sustainability appear in each spatial development framework of Heves and in Borsod-Abaúj-Zemplén Counties, as well as in the national development concept, and in each element of the target system within the county concepts. The Strategic Environmental Assessment (SEA) methodology helps in the evaluation of the sustainability of each plan. It is also useful in spatial development. The aim of SEA is to conduct a survey to correlate the data with an impact assessment matrix of sustainable criteria (value). (Pálvölgyi and Csete, 2011).

A unified guideline (218/2009 (X.6.)) was made by the competent Ministry for the final version of the development concept which serves as the basis of the process. Additionally, our research considered the methodology suggested by the UN-UNEP, which was applied in working out the Karcag Kunmadaras Egyek Local Agenda 21 pilot project in 2001 (Szlávik and Csete, 2004).
Conclusions were made considering the special features of the European administration systems (Szlávik and Horváth, 2011) and the experiences gained from strategic environmental analysis of the Hungarian Transport Strategy.

On the basis of the work of Pálvölgyi and Csete (2011), the criteria of sustainable spatial development was identified as shown in Table 1.

As our current study did not intend to conduct the SEA, we do not offer an effect-matrix but rather, we examine whether certain aims are presented in the target system of Heves County's concept, based on the central guide and, if so, which aims are represented among the above mentioned criteria of regional jurisdiction. The county framework, on the basis of these guidelines, contains a short vision related to the county and the target system which is built in every county concept as follows:

- Strategic objectives

- Overall objectives

- Horizontal objectives

We are also focusing on how the four key areas of progress toward Hungarian sustainability (drafted in the National Sustainable Development Framework Strategy, 2013) appear in each county concept. These key areas, determined as the operating conditions of sustainable development in the long term, are:

1. Investment in the production of human capital: individual- and family values, and changes in approach and lifestyle. 
2. Investment in the production of social capital: the restoration of collective- and national values.

3. Investment in reproduction of natural capital: to conserve and to use the nation's natural resources

4. Investment in the production of economic capital: to address economic interdependence and to grow national wealth.

Sustainability within a regional approach requires a valuestoring economy that provides the economic growth within the boundaries of ecological carrying capacity and the preservation of biological diversity and the quality of services provided by a natural environment. According to the explanation of strict sustainability, natural capital cannot be replaced by other capital goods. The value of the natural capital does not decrease over time. (Szlávik, 2005; Csete, 2009)

\section{Aspects of sustainability in the spatial development framework of Borsod-Abaúj-Zemplén County}

The North Hungarian region is one of the seven Hungarian statistical regions, which includes three counties: BorsodAbaúj-Zemplén, Heves and Nógrád. The region is one of the most underdeveloped regions in Hungary, according to the Hungarian Central Statistical Office (2015). The GDP per capita is less than 60 percent of the national average (and 40 percent of the EU-28 average in 2013 - according to Eurostat). The population of the Borsod-Abaúj-Zemplén County was over 680.000 in 2013. The population of Heves County was 306.000 in 2013.

The overall strategic goal of Borsod-Abaúj-Zemplén County is "taking its industrial traditions, potential labor supply, specific natural facilities and geographical position into the consideration, achieving the goal that the competitiveness of the county increases above-average to 2020 is realistic" (BAZMTFK, 2013:p.4). This establishes a very ambitious goal, expecting that the county "has a new dynamic development, future-oriented image which will appears in the public sense after that negative view the county is underdeveloped and the collapsed heavy industry generated many negative aspects" (BAZMTFK, 2013:p.3). We do not focus on the examination of this vision, but we note that the feasibility of some parts of it (such as "the half part of the total energy consumption of the county will be produced from renewable energy sources - with special regard to biomass, solar, wind, geothermal and other modern technologies and from the local coal mining" BAZMTFK, 2013:p.3) are serious challenges.

The target system of A BAZMTFK (2013) is similar to the HMTFK (2013), with regard to the regulations: to reach the overall goals some interim strategic and horizontal goals were established, but these latter ones are only in the last part of the document (in BAZMTFK, 2013:p.18). In our view, the structural solution makes the unity of the goals and their transparency difficult to realize.

The four key areas of the path to Hungarian sustainability are present in the target system but the formalization of that is far from the system of the HMTFK (2013). (Fig. 1)

The 5 overall goals are well supported by the 6 strategic objectives in the target system, the expected effects are unequivocal, but the causality relationships (the causality directions) are not always clear. In some cases we prefer the emphasis of the bidirectional connections, as opposed to the unidirectional ones. For example, increasing economic performance affects economic competitiveness and visa versa.

Hereinafter we examine how the criteria of sustainability are presented with regard to the overall, strategic and horizontal goals. In Table 2 we highlighted in bold italics those criteria which support sustainability in this concept.

In the system of overall goals, the three dimensions of economy, society, and nature are present, but in our view, are
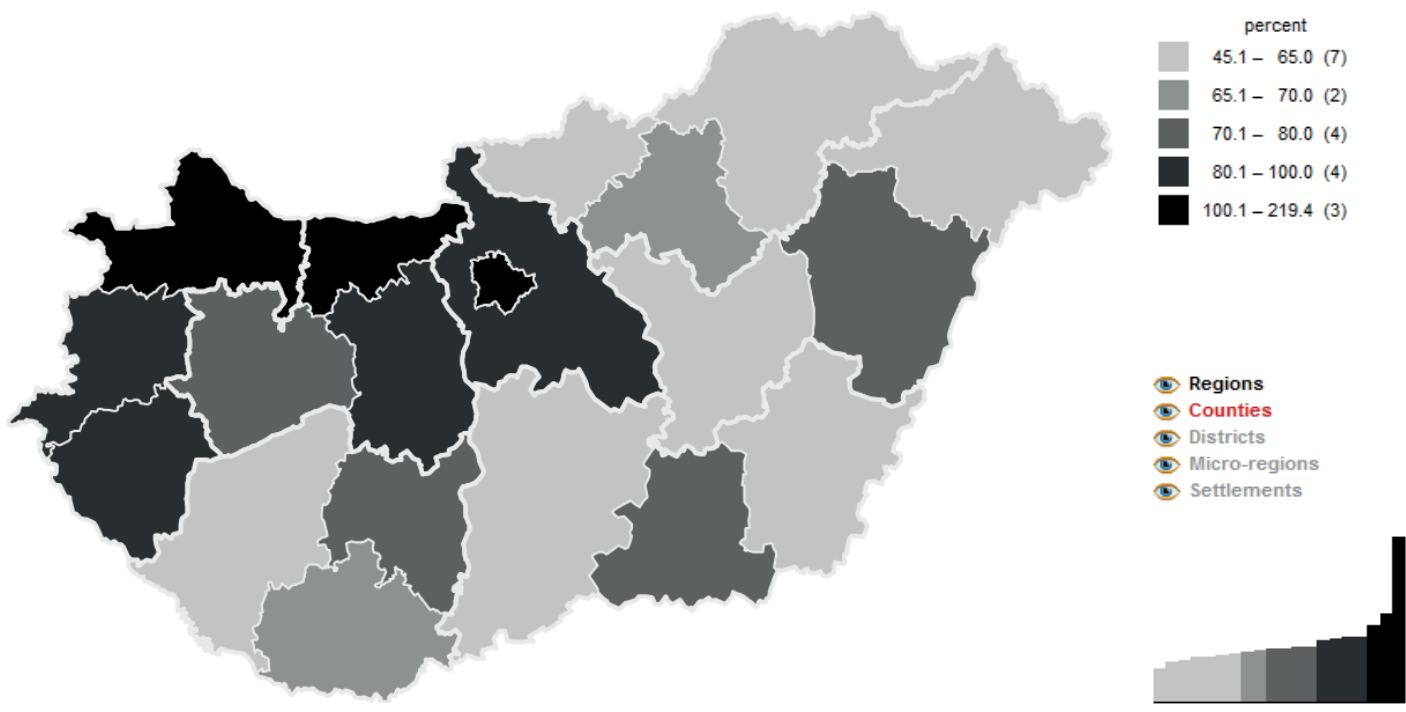

Fig. 1 Concept of spatial development in Borsod-Abaúj-Zemplén County 2014-2020: Target system; Source: own compilation on the BAZMTFK, 2013:p.6. 
Table 2 Criteria of sustainability with regard the overall goals

\begin{tabular}{l} 
1. overall goal: Increasing employment \\
\hline - $\quad$ increasing employment caused by enhanced export volume, increasing economic performance of SMEs and increased FDI. \\
- $\quad$ retain the well-educated labor stock \\
- integration of the underprivileged social groups living in outer and inner periphery into the labor market $\rightarrow$ Justice and social equality \\
between generations; Social cohesion; Social equity \\
Indicator 1: the unemployment rate should fall below 10 percent in the county by 2020.
\end{tabular}

2. overall goal: Increasing economic performance

- increasing the innovation performance of county enterprises, with special regard to engineering, chemistry, mechatronics, coal and energy industry, and electrical engineering.

- Indicator 2: the gross added value in 2020 should exceed by at least 75 percent that of 2010, in current prices

- Indicator 3: The difference between the personal income tax basis in the county and the national average has diminished in 2020 (in 2010 it was approximately 90 percent of the national average)

3. overall goal: Increasing the adaptive capacity of the society

- development of the quality of life for underprivileged social groups living in the outer and inner periphery (with special regard to education, health, and motivation) to become approved labor work $\rightarrow$ Justice and social equality between generations; Knowledge-based spatial development

- $\quad$ stop the reproduction of poverty and social exclusion, decreasing segregation and spatial disadvantages $\rightarrow$ Justice and social equality between generations; Social cohesion; Social equity

- Indicator 4: reducing by half the number living on welfare (per 1000 employees) with regard the national average. Decreasing the ratio of the underprivileged social groups, with special regard to the gipsy population.

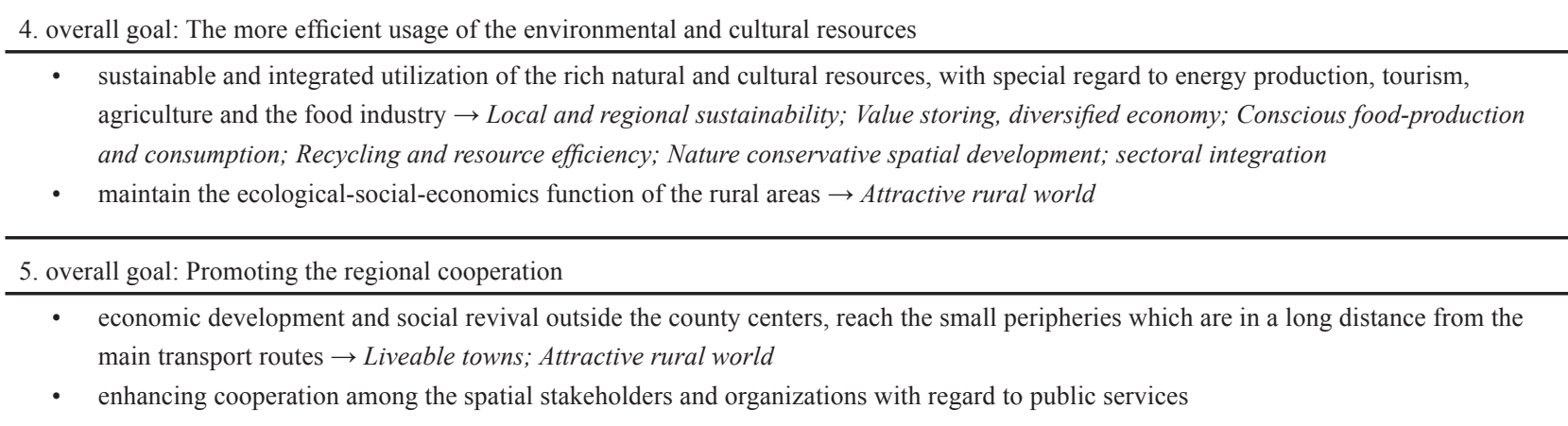

Source: own compilation on the BAZMTFK, 2013:p.4.

not coherent. The presence of the criterion of sustainability is not complete, and there is considerable overlap in some areas, including in the criteria of justice and social equality between generations.

In Table 3, the strategic goals of the BAZMTFK (2013) are presented, associated with the criteria of sustainability. These criteria are more numerous and detailed than are the strategic goals and, when combined with the overall goals, they are forward looking, but not complete. The following criteria are missing:

- Global sustainability (but it is represented by the horizontal goals);

- Diligence and altruism;

- Ethical operation;

- Ecological developments (but it is represented by the horizontal goals);

- Minimization of multiplier effects;

- Dematerialization;

- Integrated product policy;
- Decentralized developments;

- "Produce locally, consume locally!";

- "Work locally";

- Quality products and innovation;

- Solidarity and regional cohesion;

- Social participation (but it is represented by the horizontal goals);

- Local eco-social interest and social responsibility

Table 4 presents the horizontal goals of the BAZMTFK (2013) in connection with the criteria of sustainability. These objectives support well the strategically important willingness to accept responsibility and enhance a number of the criteria.

The document is coherent with regard to the strategic goals of the Concept of the National Development and Spatial Development but it includes only some of the important steps towards sustainable development. It is clear that the concept was not developed with regard to all of these criteria, but it contains many of them. 
Table 3 Criteria of sustainability regarding the strategic goals

1. strategic goal: Promoting the economical competitiveness, creating new jobs and supporting innovation $\rightarrow$ Production cooperation within the region; Knowledge based spatial development

- Technological/industrial park and high-tech zone establishment (deepen the cooperation between higher education and the economic actors)

- Territory and branch-specified developments (supporting clusters, enterprise cooperatives, and local supplier networks )

- Borsod area: Miskolc-Tiszaújváros-Kazincbarcika-Ózd

- Zemplén and Tokaj-hegyalja area

- Abaúj-Cserehát area

- Improvement in the financial sources of the economic development (giving financial support to enhance investment and employment)

$\circ$ development of the food industry, manufacturing, chemical industry, metallurgy, metal processing, engineering (with special regard to the automotive industry), environment industry, energy industry, water producing, waste management, logistics, and tourism

- Improvement in the institutional system to effectively support economic development

- Development of the logistic network (promoting logistical investments in Mezőkövesd, Miskolc, Tiszaújváros, Sátoraljaújhely, and Tornyosnémeti)

- Development of the rural areas

- Tax reduction, employment incentives and other kinds of support in the Edelényi, Encsi, Ózdi, Sárospataki, Szerencsi, Szikszói, AbaújHegyközi, Bodrogközi, Mezőcsáti, and Tokaji subregions.

- Other economic supports (development of the informatics infrastructure and improved cooperation between Slovakia and Hungary)

2. strategic goal: Increasing the adaptive capacity of the society towards labor market needs $\rightarrow$ Justice and social equality between generations; Knowledge based spatial development; Social equity

- Flexible training systems which can quickly react to changes in the economic needs and market challenges.

- Equity between disadvantaged and mainstream groups (ensure the personal social equality).

- Improvement of general public health with different kinds of programs and infrastructure.

- Improvement of social capacity through applying new solutions.

3. strategic goal: Improving the availability of the centres of the labor market

- Development of public transport (with special regard to railways).

- Environmentally-friendly solutions in the transport system; obstacle clearing and developing passenger -friendly services.

- Building a motorway between Kosice and Miskolc.

- Development of the main roads in the county, modernizing the secondary roads that are in bad condition, increasing the availability of road transport in the county.

- Improving the transport system with regard to the East gate of Miskolc

4. strategic goal: The sustainable usage of special natural and cultural resources $\rightarrow$ Conscious food-production and consumption; spatial development while conserving natural resources; Value storing economy with renewable resources; Liveable towns; Attractive rural world

- Sustainable utilization of natural and cultural resources with special regard to their tourism potential.

- Vegetable, fruit and animal production and the promotion of the local food industry (using heat energy in the greenhouses and sustainable water management, development of warehousing, sales and distribution systems, enhancing the capacity of farming, ecological rehabilitation of wetlands, facility -based development of farmlands, and improvements to agricultural tourism)

- Development of mining and heavy industry.

5. strategic goal: Promoting renewable energy consumption $\rightarrow$ Sparing use of exhaustible resources; Value storing economy with renewable resources; Recycling and resource efficiency

- Using renewable energy sources with local decentralization of energy production, storage distribution and integrated systems (biomass-based energy production, "1 village - $1 \mathrm{MW}$ " program, the development of smart grid, wind energy, and the better utilization of water and geothermal energy sources)

- Decreasing energy consumption and promoting renewable energy sources with regard to the general public, institutions and enterprises, while minimizing the energy lost in the production and distribution systems.

6. strategic goal: Improving the state of the environment and developing environmental security $\rightarrow$ Pollution prevention and minimization; Recycling and resource efficiency

- Increasing recycling of industrial waste

- Inland water protection, flood prevention, building rainwater drainage systems, and reconstruction of the reservoirs and retention basins.

- Improving the environmental quality of life, with special regard to underprivileged social groups.

- Saving the natural land and cultural values, maintaining a high standard of environmental quality which ensures employment opportunities for the local inhabitants and preserves the attractiveness of the rural areas.

- Waste water treatment and land rehabilitation.

- $\quad$ Preserve biodiversity.

Source: own compilation on the BAZMTFK, 2013:pp.6-18. 
- Sustainable environment and land use (preservation of the natural value and water sources while decreasing air pollution and waste production).

- Consideration of the settlement plans in the county $\rightarrow$ Local and regional sustainability; Global sustainability; spatial development while conserving natural resources; Ecological development; Recycling and resource efficiency; Sparing use of exhaustible resources

- $\quad$ use of brown fields, and reuse of unused buildings and fields instead of new green field investments

- $\quad$ integration of underprivileged social groups (social equity) and spreading of positive development effects $\rightarrow$ Social equity; Justice and social equality between generations; Social participation

- $\quad$ applying modern information and communication technologies (ICT) to ensure the spread of information to underprivileged social groups $\rightarrow$ Knowledge-based spatial development

Source: own compilation on the BAZMTFK, 2013:p.18.

\section{Aspects in sustainability in the spatial development framework of Heves County}

Heves County focuses, in its long-term spatial development framework, on a vision that is considered by social- and economic operators as a desirable, ambitious and realistic concept:

"By its innovation-oriented, competent, and predictablydeveloping economy based on properly trained and trainable human capital, by the sustainable use of its natural resources and the continuous improvement of its social resources, and by creating workplaces and its ever-improving public safety, Heves County will have become an important actor of the national economy by 2030. (HMTFK, 2013:p.4)

During the implementation of this vision, the enforcement of the principles applied in the European Union are especially important, which also define the feasibility of the development program and the method of its implementation. These goals, especially sustainability, must be taken into account during the county's planning. (HMTFK, 2013):

- sustainable development: it should be sustainable in the long term, it should be balanced under the socialeconomic-environmental criteria, and it is able to selffinance well-aimed developments in the long term.

- equality: beneficiaries of the implemented developments include every group in the society, in order to have freedom in personal development, enrichment, social success and the well-being of the citizens in the county and not to be limited in ethnical, gender, religious, political and income differences.

- partnership: the development program is based on the collaboration of the county's operators, jointly-mobilized and related to common goals; cooperation is needed between central and local institutions, organizations, and the private sector.

- additionality: the development program has its own authority in the county, because the long term goal mainly means the support of the programs where beneficiaries receive additional support, in addition to their own resources.
After defining the vision and principles, a target system was established to serve the implementation, containing three overall goals, seven strategic goals (four complex and three spatial strategic) and ten horizontal goals (see Table 5, 6, 7).

The development of the county has reached a new quality phase. In this phase, infrastructural and institutional services have to be enlarged continuously, improving factors that can help improve the quality of production and living conditions are also needed. An increasingly large part has to be invested from available resources to improve the population's living conditions. These include the improvement of education and training quality, the improvement of the state of the environment, storing the values of habitations and regions, and renewing the factors that define the quality of human housing areas. At the same time, a categorization of the regions and social groups is required, along with the settlement of the activities and organizations supporting the propagation of innovation processes and the development of the economic basis. (HMTFK, 2013)

The county can be divided into three regional units, each requiring a different kind of development. The middle part of the county includes the most significant businesses $(90 \%$ of capital investment, $89.7 \%$ of added value). The majority of the population lives here (69\%), in what is essentially an urban region possessing a significant innovation potential. The northern part of the county is a mountain region, more economically foreclosed and socially disadvantaged. The number of settlements/habitations is high but the total population is quite low. Nevertheless, excellent tourist benefits from the natural landscape are available in the region. The southern part of the county is also disadvantaged, but its availability for development is better and the effects of climate change can be seen here. The region lost its former industry but Lake Tisza, as a complex development area, differs from the rest of this region.

Examining the spatial development plan of Heves County, it can be seen that the overall and strategic objectives integrated to the horizontal visions were defined in connection with the key areas in the transition to sustainability. In our study, we 


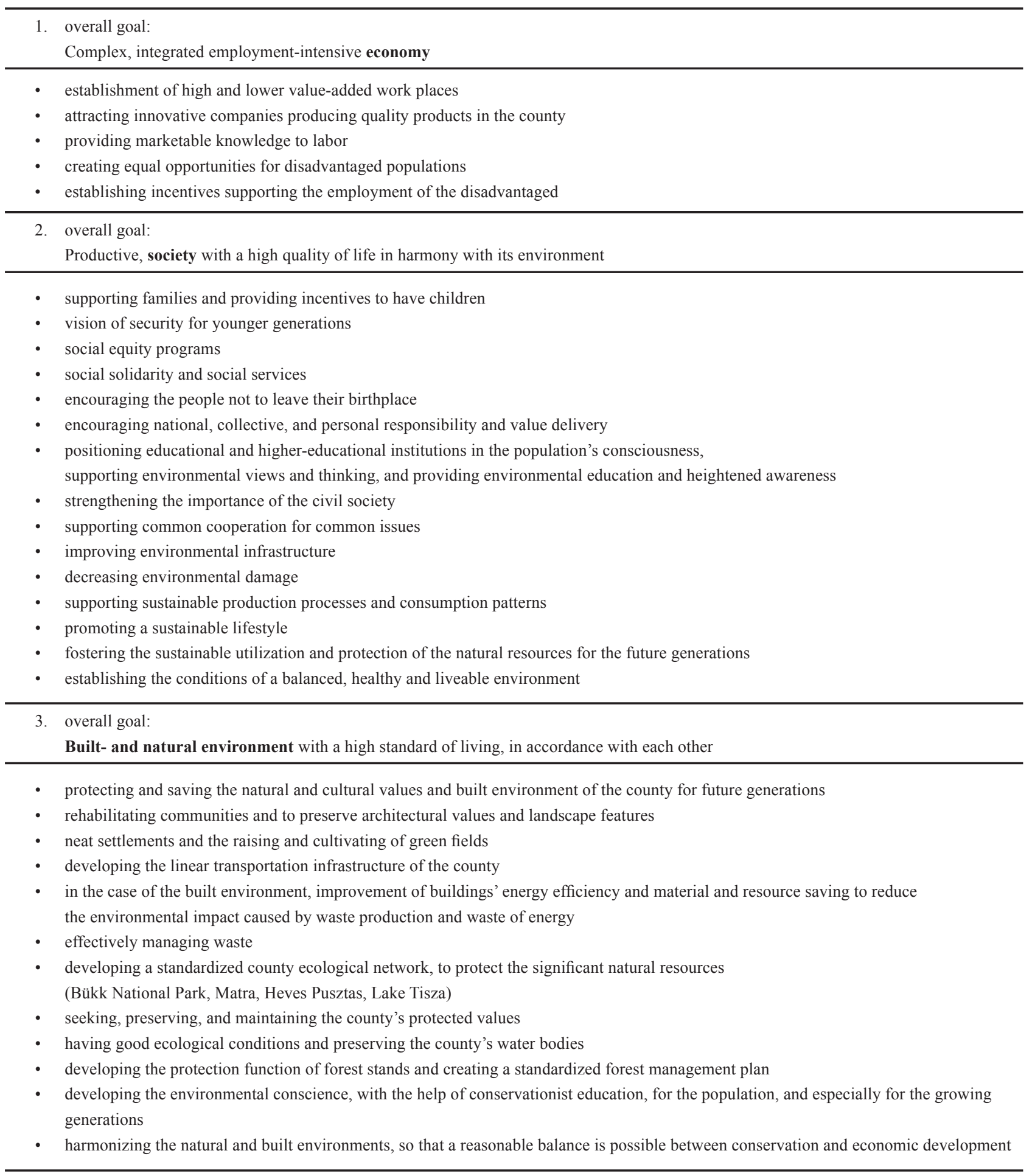

Source: own compilation on HMTFK (2013)

focus on the overall and strategic objectives on the basis of the establishment of spatial sustainability criteria. The following table offers a better view of this. We then survey the relationship of the horizontal objectives to the views of sustainability. We show the spatial sustainability of the criteria appearing in overall goals in Table 5 .

We can see that, during the drafting of the overall goals, economy, society and nature were taken into consideration and expected to involve more spatial sustainable criteria.
In reviewing the listed elements related to sustainability, torn from the details of the descriptions of each goal, and comparing them to the criteria found in Table 1, it is clear that almost all of the criteria were incorporated into the plans of Heves County. There are only a few criteria that cannot be found (e.g. knowledge-based regional development and sectoral integration), but these are also included in the following strategic objectives. In Table 6 the spatial sustainable criterions found in strategic objectives of HMTFK 2010-2020 are shown. 
1. Strategic (spatial) objective:

Hatvan-Gyöngyös-Eger strengthening the "economic priority"

- developing innovation potential in order to strengthen and retain a competitive economy

- strengthening cooperation between businesses

- strengthening local suppliers' cooperation and the development of stronger partner networks

- local usage of natural resources, developing the environmental industry

- strengthening the sales potentials of locally-produced products

- managing complex landscape rehabilitation and landscape reconstruction

- protecting water supplies in surface and subterranean basins

- developing the local and collective transportation system in an environmentally-friendly way

- improving energy efficiency through alternative, local energy production based on renewable energy and the building of supply systems

- quality improvements in the local health industry based on natural medicinal factors

- supporting tourism development based on individual natural conditions, cultural values and wineries

- strengthening the welcoming image and experience of towns

2. Strategic (spatial) goal: Development of the nature-centred Northern-Heves region

- strengthening the income-generation and innovation potential of small and medium-sized enterprises

- increasing local employment

- developing digital society through information infrastructure development, with the help of increasing SME capital assets and the capacity of society

- developing rural and ecotourism among local conditions

- improving the equity of disadvantaged groups through the development of human resources

- supporting local initiatives promoting community partnership and self-preservation

- strengthening subsistence ability and supporting rural subsistence economy

3. Strategic (spatial) goal: development, built on the local values of the regions of Southern-Heves and Lake Tisza

- $\quad$ utilizing rich sun, wind, geothermal, and biomass energy

- developing digital society through information infrastructure development, with the help of increasing SME capital assets and the capacity of society

- improving the equity of disadvantaged groups through the development of human resources

- $\quad$ expanding the social economy by creating and inspiring the subsistence economy

- developing the landscape and urban environment

- $\quad$ integrating water management to create sustainable landscape systems

- creating an economic structure supporting the ecological system of Lake Tisza

4. Strategic goal: economic development based on local potentials

- $\quad$ strengthening the efficiency and spread of innovation activities

- $\quad$ supporting renewable energy resources

- $\quad$ supporting capacity creation to fuel needed operating energy production facilities based on biomass

- $\quad$ supporting investments aimed at utilizing renewable energy resources

- $\quad$ encouraging renewable energy use by smaller communities

- increasing energy efficiency during building reconstruction programs

- $\quad$ supporting the animation of the local economy with the help of new, innovative solutions

- developing concerted regional tourist infrastructure

- developing an economic strategic perspective based on business and consumer awareness

5. Strategic goal: Rural development based on local potentials, employment-centred agriculture

- development of cooperation with marketing chains

- technology development conformed to climate change

- creation of agrarian structure adapted to land use

- increasing energy security of rural economy

- creation of liveable and attractive rural world, encouraging the population to stay in the region

- communal feeding based on local foods

- increasing consumer awareness

- $\quad$ supporting the market access of local products

- creation and management of local markets

- information systems to promote and sale of local foods

- optimal use of local resources

- $\quad$ increasing the proportion of renewable to non-renewable resources

- utilize the potential of rural tourism

- improvement of social economy in rural regions

- strengthening and enlarging of common services

- improvement of rural regions with the help of the citizens' active cooperation

- strengthening civil society, encouraging the population in self-organization

- $\quad$ saving and supporting of special knowledge of local population

- $\quad$ protection of rural natural and cultural heritage 
6. Strategic goal:

Value and health-conscious, solidarity-based society, opened to receive innovation

- $\quad$ promotion of local values of sport

- $\quad$ supporting sport camps and the renovation of open-air schools

- increasing sports missions in health promotion and in the prevention of addiction

- involving handicapped persons in sporting life, supporting integration

- programs promoting the population's enlightenment in the fields of healthy life styles and nutrition

- development of geographical (regional) and specialized supply improvement programs and their realization through social cooperation

- complex improver and supporter programs for long-term employers

- $\quad$ reducing poverty and child poverty

- $\quad$ programs aimed the employment of lagging groups

- $\quad$ strengthening the power of regions

- direct programs for Roma children's improvement and for reducing their job market disadvantages in order to get over social- and social-cultural disadvantages

- $\quad$ strengthening the access for children's equal opportunity services

- $\quad$ supporting social urban regeneration and social housing

- development of social economy and inciting local, social, economic programs and creation of organizations

- $\quad$ subsistence rural programs, development of local communities

- $\quad$ supporting the social activities of civil groups and churches

- increasing prevention and knowledge related to crime, prevention of criminal career

- strengthening the family as the basic unit of society

- flexible working hours at work places, supporting the introduction of part-time employment or teleworking

- $\quad$ inciting the creation and adaptation of collective-social innovations

- development of local identity in schoolwork improvement

- $\quad$ strengthening self-esteem, local-, regional-, national awareness- and togetherness with the support of collective culture

7. Strategic goal: Strong towns, liveable rural regions, a sustainable environment and spatial structure

- development of public transport and the building of bypasses in order to decrease the dangerous effects related to transport

- water basis including flood and inland water protection

- modern waste water engineering

- $\quad$ efficient waste management, reducing the disposal of waste

- reducing air pollution and noise pollution

- $\quad$ protection of nature preserves

- rationalization of environmental standards

- environmentally-friendly energy developments and the realization of natural investments

- $\quad$ sustainable regional and spatial structure

- $\quad$ equalizing regional development differences

- development of the innovative potential of cities

- $\quad$ supporting collective civil organizations and the strengthening self-organization

- $\quad$ increasing the equity of lagging regions

- development of integrated regional cooperation and local improvement organized by the community

- ensuring equal access for information for information communication development

- access to electronic public services on a wider scale

Source: own compilation on HMTFK (2013)

It can be concluded that the listing of sub-targets, among the strategic-related targets - the ones relating to sustainability, collected in the table above, and their correlation with the regional sustainability criteria are complete. All of the criteria detailed in Table 1 can be found in the overall or strategic objectives of HMTFK 2014-2020. In the case of certain fields each criterion appears several times.

The mentioned ten strategic objectives are also supported by ten horizontal objectives, increasingly harmonized with each other to ensure the economic, human, social, and natural capital needed for development. (HMTFK discussion, 2013) The planning concept of Heves County is based on these horizontal theories, reflecting the connections of the target system. Table 7 illustrates the content of the horizontal objectives, grouped according to the four key areas of sustainability, and also the types of sub-targets in the planning concepts of Heves County in the planning period of 2014-2020.

Further messages are also defined by HMTFK 2014-2020 for economic operators, citizens, families, villages, towns, churches, legislatures, and law enforcement officials. These messages are not detailed but the information included in them is incorporated in at least $50 \%$ of the realization of the transition toward sustainability. 
Table 7 Criteria of sustainable spatial development in the horizontal objectives of HMTFK

\begin{tabular}{|c|c|}
\hline \multirow[t]{2}{*}{ Human capital } & $\begin{array}{l}\text { Talent promotion: } \\
\text { - offering high quality education in order to strength intellectual potential } \\
\text { - } \text { staying in the county after graduation } \\
\text { - attracting talented young people to Heves County from outside the county } \\
\text { - development of a career program for talented young people }\end{array}$ \\
\hline & $\begin{array}{l}\text { Working culture: } \\
\text { - working culture is one of the basic terms of sustainable development } \\
\text { - certain aspects must be improved: language knowledge, communication, risk-taking, responsibility, cooperation, } \\
\text { motivation and problem solving skills }\end{array}$ \\
\hline \multirow[t]{2}{*}{ Natural capital } & $\begin{array}{l}\text { Sustainable "green county": } \\
\text { • } \quad \text { society living in harmony with nature } \\
\text { - } \quad \text { social awareness } \\
\text { • } \quad \text { economic sector responsible to local society }\end{array}$ \\
\hline & $\begin{array}{l}\text { Quality of life: } \\
\text { - preservation and careful development of environmental and natural systems } \\
\text { - } \text { creation of a liveable natural environment } \\
\text { - } \text { sustainable protection and development of resources in the natural and built environments } \\
\text { - } \text { realization of material and energy efficiency }\end{array}$ \\
\hline \multirow[t]{3}{*}{ Economic capital } & $\begin{array}{l}\text { Innovation: } \\
\text { - } \quad \text { innovation based on skills and knowledge } \\
\text { - development of IKT culture in SME sectors } \\
\text { - development of cooperation between research units and business sectors } \\
\text { - } \quad \text { social economy primarily oriented for "low-tech" activities }\end{array}$ \\
\hline & $\begin{array}{l}\text { Competitiveness: } \\
\text { - utilization of the possibilities of natural endowments } \\
\text { - } \text { ensuring work and quality of life for less qualified employers } \\
\text { - utilization of bio-energy } \\
\text { - } \text { education and the integration of young people into formal education } \\
\text { - } \\
\text { reducing demographic processes }\end{array}$ \\
\hline & $\begin{array}{l}\text { Efficiency: } \\
\text { - } \quad \text { time efficiency, cost efficiency, and sustainability } \\
\text { - } \text { professional and public media coverage with more information for both the representatives of the professional and public } \\
\text { groups } \\
\text { - labor efficiency }\end{array}$ \\
\hline \multirow[t]{3}{*}{ Social capital } & 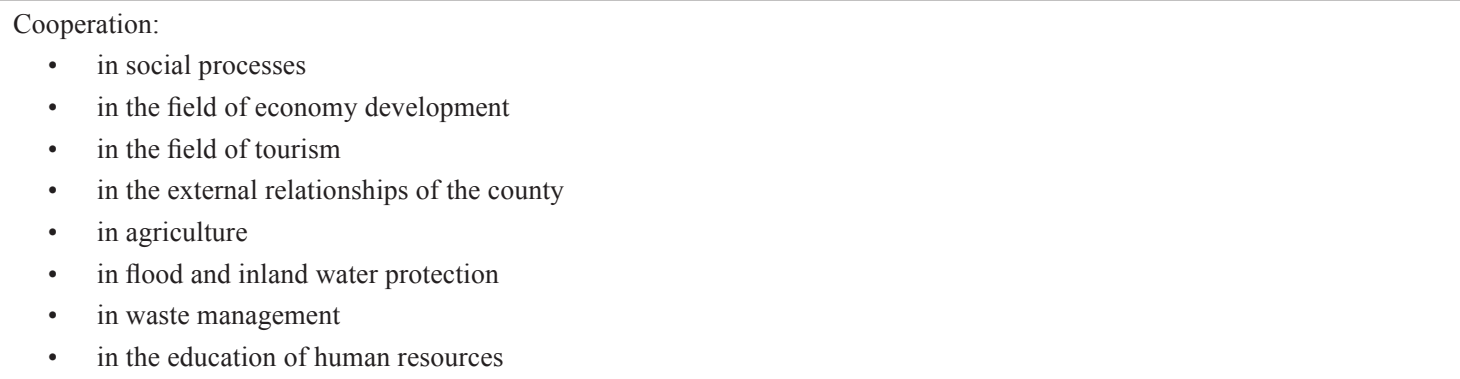 \\
\hline & $\begin{array}{l}\text { Equality: } \\
\text { - increasing the opportunities of the equality target groups. } \\
\text { - improvement of the situation of impoverished groups } \\
\text { - improvement of social equity and the integration of minorities and disadvantaged groups } \\
\text { - strengthening regional equality } \\
\text { - providing access for information and knowledge }\end{array}$ \\
\hline & 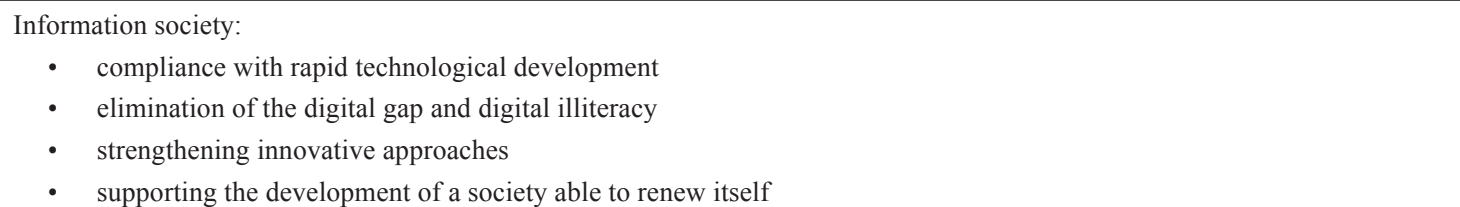 \\
\hline
\end{tabular}

Source: own compilation on HMTFK (2013) 


\section{Main differences between the concepts of Borsod- Abaúj-Zemplén and Heves County}

One of the most important criteria is "Diligence and altruism", which "ensures the enforcement of the principle of the good owner, but does not hurt the values and interests of other communities, and it should not lead to the increase of regional differences". The other one is "Decentralized developments", which states "the regional development plans should not result in the concentration of enterprises and should support the diversity, race equality and the development of the local economies and trade" (Pálvölgyi and Csete, 2011:p.472). Regarding these two criteria, there are serious differences between the concepts. In the short run, the spatial development framework of BorsodAbaúj-Zemplén County does not focus on the decrease of the regional differences. Instead, it mainly emphasizes the support of the "centers which have a willingness to grow", noting that "serious shift from the current situation of the county can be reached only with a strategy focusing on the internal capabilities" (BAZMTFK, 2013:p.4). According to the concept's authors, just through concentrated developments can it be a success and that it is essential to reach the two most important goals - increasing employment and adding value.

The spatial development framework of Heves County divides the territory into three main parts and it determines separate strategic goals for each which are adapted to the overall goals (such as HMTFK, 2013:p.5)

One of the main advantages of the spatial development framework of Borsod-Abaúj-Zemplén County is that it sets up several indicators. It determines four indicators for the overall goals, which are a priority to complete by 2020 . The spatial development framework of Heves County does not contain measurable indicators, but it can be explained with the ecological-environmental view of the authors in that they focused primarily on a qualitative versus a quantitative approach.

Serious differences between the two concepts can be observed in the strategic goals. While the spatial development framework of Borsod-Abaúj-Zemplén County uses a horizontal approach, the spatial development framework of Heves County drafts solutions with a geographical perspective. Heves County approaches the strategic goals differentially and plans the development of the Hatvan-Gyöngyös-Eger, the NorthHeves and South-Heves/Tisza-lake axes in a different way. Of course the necessary steps are also different. For example, the type of natural environment chosen for concentration or the focus of a development plan for the economic axes uses other instruments. In the spatial development framework of BorsodAbaúj-Zemplén County, the development goals focusing on spatial units are concentrated into one subpart.

\section{Conclusion and recommendations}

There is no "only one" correct general sustainable value. The criteria and approaches mentioned in the study represent a number of approaches to help control outcomes and serve as a benchmark for assessment. In our study the existence of approaches were only examined. Their relations to each field must be further explored. The question "where are we on this path?" can only be answered after several years, and even then a final answer can be hardly given. Can the regional sustainable criteria involved in the spatial development framework of the county be incorporated into the programs, what the effects would be, and how the development of these objectives would contribute to the realization of the transition toward sustainability? One thing may surely be said. Taking into consideration the sustainability criteria and our regional development objectives and trying to reach these objectives on the basis of these details, we are on the right track.

\section{References}

BAZMTFK (2013) Spatial Development Framework of Borsod-AbaújZemplén. Discussion. [Online] Available from: http://www.baz. hu/content/cont_510904de8203c2.49102793/BAZ_megye_konc_ jav_20130219.pdf [Accessed: April 2013]

Bujdosó, Z., Dávid, L., Kovács, T. (2013) Regional policies in the European Union with special regard to Central Europe. In: Education and awareness-raising - the key to understand EU enlargement process. Express your voice - Challenges and benefits of future EU enlargements. pp. 234 241. University of Economy in Bydgoszcz, Poland.

Csete, M. (2009) A fenntarthatóság kistérségi vizsgálata. (Study on the sustainable territorial development.) Ph.D. thesis, Budapest University of Technology and Economics, Budapest, Hungary. (in Hungarian) URL: http://www.kornygazd.bme.hu/doktori/phds/DSZ0709/CseteM/Csete ertekezes.pdf

Delladetsima, P. M. (2012) Sustainable Development and Spatial Planning: Some considerations arising from the Greek case. European Journal of Spatial Development, 21 p. URL: http://www.nordregio.se/Global/ EJSD/Refereed\%20articles/refereed46.pdf

Dinya, L. (2012) Fenntarthatóság alulnézetben - a fenntartható kistérség modellje. (Sustainability from a bottom view - local model of the sustainability.) A FALU, 28(1), pp. 29-40. (in Hungarian)

European Comission (2010) Europe 2020 - A strategy for smart, sustainable and inclusive growth. [Online] Available from: http://ec.europa.eu/eu2020/ pdf/COMPLET\%20EN\%20BARROSO\%20\%20\%20007\%20-\%20 Europe\%202020\%20-\%20EN\%20version.pdf [Accessed: April 2013]

Informal Ministerial Meeting of Ministers responsible for Spatial Planning and Territorial Development (2011). Territorial Agenda of the European Union 2020 (TA2020) - Towards an Inclusive, Smart and Sustainable Europe of Diverse Regions. [Online] Available from: http://www.euterritorial-agenda.eu/Reference\%20Documents/Fina1\%20TA2020.pdf [Accessed: April 2013]

Kawakami, M., Shen, Z.-J., Pai, J.-T., Gao, X.-S., Zhang, M. (2013) Spatial Planning and Sustainable Development - Approaches for Achieving Sustainable Urban Form in Asian Cities. Journal of Regional Science. 54(5), pp. 927-930. DOI: 10.1111/jors. 12170 
Kiss, G. (2014) Why Should the Public Participate in Environmental DecisionMaking? Theoretical Arguments for Public Participation. Periodica Polytechnica Social and Management Sciences. 22(1), pp. 13-20. DOI: 10.3311/PPso.7400

Kocziszky, Gy. (2013) Experiences of Hungary's Regional Economic Development, Equilibrium and Regional Policies. DIANZI KE-JI DAXUE XUEBAO / Journal of University of Electronic Science and Technology of China (social sciences edition). 15(6), pp. 30-35.

Kovács, T. (2012) Fejlesztéspolitika a demográfia szoritásában: a zsugorodó térségek és városok problematikája. (Development policy with regard the demography tendencies: the problems of the shrinking spaces and cities.) Líceum Publisher, Eger. (in Hungarian)

HMTFK (2013) Spatial Development Framework of Heves Megye 2014-2020. [Online] Available from: http://www.hevesmegye.hu/files/koncepcio/ HMTFK_jm_v2.37.pdf [Accessed: April 2013]

LISBON EUROPEAN COUNCIL (2000) PRESIDENCY CONCLUSIONS Lisbon strategy. [Online] Available from: http://www.europarl.europa. eu/summits/lis1_en.htm [Accessed: April 2013]

National Sustainable Development Council (2013) National Sustainable Development Framework Strategy. [Online] Available from: http://nftt.hu/ nemzeti-fenntarthato-fejlodesi-keretstrategia/ [Accessed: December 2015]

Natural Resources Defense Council (2012) Sustainability report. [Online] Available from: http://www.nrdc.org/about/sustainability/files/nrdc-sustainability-report-2012.pdf [Accessed: April 2013]

OFTK (2012) Nemzeti Fejlesztés 2020 - Az Országos Fejlesztési Koncepció és az Országos Területfejlesztési Koncepció társadalmasítási egyeztetési változata - vitaanyag. (National development.) Nemzetgazdasági Tervezési Hivatal. (in Hungarian). [Online] Available from: http://www. nth.gov.hu/files/download_files/504/oftk_tarsadalmi_egyeztetes_1217. pdf [Accessed: April 2013]
Pálvölgyi, T., Csete, M. (2011) A fenntarthatóság felé való átmenet lehetőségei Magyarországon. (The facilites of shift to the sustainability in Hungary.) Gazdálkodás, 55(5), pp. 467-478. (in Hungarian)

Ruszkai, Cs., Kovács, T. (2013) The Community Initiative LEADER I and the implementation and results of the Hungarian Pilot LEADER programme in rural development. In: Bulletin of Geography. (Szymańska, D., Biegańska, J. (eds)), Socio-economic Series. 19. Nicolaus Copernicus University Press, Toruń. pp. 87-97. DOI: 10.2478/bog-2013-0006

Szlávik, J. (2005) Fenntartható környezet- és eröforrás-gazdálkodás. (Sustainable environment and resource economics.) KJK Kerszöv Publisher, Budapest. (in Hungarian)

Szlávik, J., Csáfor, H. (2013). Fenntarthatósági szempontjainak megjelenése a területfejlesztésben - Heves megyei területfejlesztési koncepció példáján. (The presence of criteria of the sustainability in the territorial development.) In: Régiók fejlesztése conference. (Buday-Sántha, A., Danka, S., Komlósi, É. (eds.)), pp. 163-177. Pécs. (in Hungarian)

Szlávik, J., Csete, M. (2004). A fenntarthatóság érvényre juttatása települési kisregionális szinten. (Enforcement of sustainability in local subregional level) Gazdálkodás, 48(4), pp. 10-27. (in Hungarian)

Szlávik, J., Horváth, Gy. Á. (2011) To topicto - mikroperifereiakto epipedo bioso motitas. In: (Sifis Balyrakhis, Stergios Babanasis (ed.)) Papazisi, Athén. pp. 85-104. (in Greek)

Szlávik, J. (2013) Fenntartható gazdálkodás. (Sustainable economy). Wolters Kluwer CompLex Kiadó, Budapest. (in Hungarian)

218/2009(X.6.) Government Regulation - No1 appendix (Kormányrendelet 1. számú melléklet) [Online] Available from: http://net.jogtar.hu/jr/gen/ hjegy_doc.cgi?docid=A0900218.KOR [Accessed: December 2015] 